\title{
Weakness in Numbers: \\ Towards an Understanding of Employees of Color's Responses to Organizational Research Efforts
}

\author{
Vickie Cox Edmondson \\ The University of Alabama at Birmingham \\ Jodi Barnes \\ North Carolina State University \\ Gouri Gupte \\ The University of Alabama at Birmingham
}

\begin{abstract}
Employees of color have been reluctant to respond or to give candid responses when participating in organizational research, putting its validity at risk. In this literature review, we examine how employees of color's assessment of and satisfaction with an organization's commitment to diversity affect their willingness to participate in organizational research efforts in multicultural organizations. Two general propositions are explored but not tested: (1) responding openly is of little or no utility to employees of color, and thus responding is of no genuine value, and (2) responding candidly could lead to adverse consequences for them.
\end{abstract}

\section{Introduction}

Organizational research is often designed to solve practical problems in the business environment such as assessment of needs, making policy decisions, long-range planning, communicating what is important to stakeholders, and gaining employee feedback. However, some employees refuse to participate in organizational research or will not provide candid feedback to effectual audiences during the process. Thus, management's ability to adequately understand, evaluate, and improve the organization's well-being and effectiveness by assessing the perceptions and attitudes of this primary stakeholder group is limited. Of central interest in this paper are the perceptions, beliefs and behaviors of employees of color toward organizational satisfaction surveys and like attempts to gather perceptual data in regard to competitive strategies.

People of color have been reluctant to respond to organizational research - particularly organizational satisfaction surveys - (Birnbaum \& Weston, 1974) or to do so with full candor. Consequently, while such research might yield data that are reliable across time, the validity of these data as they reflect true perceptions and beliefs is highly questionable. The absence of varied perspectives in the decision-making process may prevent the identification and critical examination of decision alternatives, and thus curb performance gains (Watson, Kumar, \& Michaelsen, 1993; Jackson, May, \& Whitney, 1995). 
Among options for gathering information about organizations, survey research methods offer unique inferential power to understand populations (Groves, Cialdini \& Couper, 1992). However, the difficulty associated with studying racioethnic groups has impelled academic researchers (Cox, 2004; Sutton \& Schurman, 1988) to suggest the abandonment of survey research in favor of qualitative research methods. Yet, survey research is popular with practitioners and managers because it is efficient and can be used for a variety of purposes (Church, 2001; Cox Edmondson, 2006). Moreover, employees are familiar with surveys, and survey methodologists are committed to improving their effectiveness (Simsek \& Veiga, 2001). Thus, when race or ethnicity has potential salience, the researcher - academic and practitioner alike - will most likely use survey research, at least in the identification phase of research design.

A large volume of extant literature addresses methods to increase participation in field surveys which may be helpful in organizational research. However, the thrust of this discussion is not to address methodological issues regarding non-response from employees of color (i.e. survey design), or to address the attitudes of employees of color toward surveys in general (i.e. assessing the value of survey research or their attitudes about the actual act of filling out a survey; Rogelberg et al., 2006). Rather, we offer insights about employees of color's perceptions, beliefs and behaviors that suggest they deem it in their best interest not to respond or not to respond candidly to organizational research efforts. While some extant research may have been directed towards increasing participation level of respondents based on race, the literature has rarely been guided by a set of theoretical or empirical rationales that seeks to explain why participation levels among persons of color, particularly employees of color in organizational research, has been less than desired.

In this paper, we examine how employees of color's assessment of and satisfaction with an organization's commitment to diversity affect their willingness to participate in organizational research efforts in multicultural organizations. Previous research has made distinctions between assessment and satisfaction and we make this distinction, as well. Riordan, Gatewood and Barnes Bill (1997) regard assessment and satisfaction to be different constructs of the employee's reactions to the actions of corporate leaders. Assessment refers to the employees' overall cognitive evaluation about the adequacy of the decisions and behaviors of their leaders. Satisfaction, on the other hand, indicates the employees' overall affective reaction towards these leaders.

We posit that people of color in organizations tend to share perceptions and beliefs, and that based on their assessment of and satisfaction with an organization's commitment to diversity-including trust in management - they decide that participating in organizational research is fruitless or potentially unwise. We also argue that not participating in organizational studies, particularly organizational satisfaction surveys, is 
a form of voicing dissent. Thus, insights into rationales for their concerns are important, especially organizationally-related matters that can be addressed prior to initiation of the research.

We begin with a literature review on managerial/organizational trust, then proceed by identifying mediators of trust that can strengthen or weaken employees of color's perceptions and beliefs about an organization's commitment to their welfare. These help determine the employee's choice to fully participate in, to not participate in, or to not respond candidly to organizational research. We provide a diagrammatic figure to illustrate employees of color's potential responses to organizational research efforts. Two main propositions are presented: (1) responding openly is of little or no utility to employees of color, and thus responding is of no genuine value, and (2) responding candidly could lead to adverse consequences. We then support the propositions with theoretical and empirical rationales. Finally, we offer practical suggestions for organizational leaders and directions for future research.

\section{Challenges Regarding Managerial/Organizational Trust}

Trust, an important component in the decision-making process, has been conceptualized by different authors in various ways. Glaeser, Laibson, Scheinkman, and Soutter (1999) define trust as "the commitment of resources to an activity where the outcome depends upon the cooperative behavior of others." Rousseau, Sitkin, Burt, and Camerer (1998) define trust as a psychological state comprising the intention to accept vulnerability based upon positive expectations of the intentions or behavior of another, (p. 395). We agree with Robinson (1996) who defines trust as "one's expectations, assumptions or beliefs about the likelihood that another's future actions will be beneficial, favorable, or at least not detrimental to one's interests." The evidence of trust is "the willingness of a party to be vulnerable to the actions of another party" (Mayer, Davis, \& Schoorman, 1995). Violations of trust result in lower subsequent trust thresholds and may reduce the extent to which self-perceived victims of these violations cooperate with the perceived offender (Dirks \& Ferrin, 2001).

One of the most difficult decisions for an individual to make is whether to trust another person (Perrone, Zaheer, \& McEvily, 2003). In an organizational context the decision is further complicated (Fukuyama 1995; Zucker 1986). Black Americans, in particular, have historical reasons to be more suspicious of Whites - the group that collectively holds the highest management positions and highest pay levels in U.S. multicultural organizations. Thus, race may further complicate trust perceptions and decisions (i.e., beliefs, behaviors) based on these perceptions. Yet, examining the influence of race has not been a specific aim of researchers in the study of managerial trust; hence, race has not been discussed at all (e.g., Atkinson, 2004; Gomez \& Rosen, 2001) or has not been explored in detail (e.g., Werhane, 1999). As reflected by most management 
literature, when race is concerned, the trust literature has been geared toward identifying differences between White and Black Americans (e.g., Key \& Cox Edmondson, 1999). Thus, little is known about how managerial trust influences the perceptions and behaviors of other racioethnic groups. Moreover, little is empirically known about how and why trust differences exist between Blacks and Whites and what interventions might raise trust levels.

Researchers have asserted that a binary racial system comprised of Whites and Blacks exists (Hacker, 1995) or that a binary system comprised of Whites and "other Americans" exists (Aranda and Rebollo-Gil, 2004). While much of the research which studies Blacks and Whites can be and is often extrapolated to other racioethnic groups, we take caution in assuming that all White ethnic groups would perceive that they are treated as White (European) Americans. In particular, for White Hispanics, racial markers such as culture, language, and global position offset the benefits of White privilege (Arnanda \& Rebollo-Gil, 2004).

However, based upon U.S. history, it is plausible that non-White racioethnic group members may perceive that they are treated similarly to Blacks. First, a history of prejudice and discrimination against people of color in the U.S along with the ostensible tensions among Blacks toward Whites (and vice versa) could likely lead to negative expectations regarding the fairness of future events and outcomes at work among nonWhites (Atwater, 1988; Ritter, Fischbein, \& Lord, 2005). Thus, other people of color may be less trusting of Whites in leadership positions. Second, the U.S. government acknowledged the need to protect non-Whites from discrimination in the workplace and society, as evidenced by the Civil Rights Act of 1964 and its creation of the Equal Employment Opportunity Commission. The perceived need for affirmative action in the U.S. remains a hotly charged issue. Further, inequities such as Whites' monetary compensation for comparable work (Werhane,1999) and status in organizations disproportionately exceeds those of other racioethnic groups, may influence (e.g., hinder, discourage, prevent full or candid disclosure among) non-White employee responses.

We can draw germane conclusions from two empirical studies that examined differences in managerial trust between Whites and people of color and found that race matters. After studying supervisor-subordinate dyads that differed in race, JeanquartBarone (1993) found that Black employees trust their White supervisors significantly less than they trust Black supervisors. Although White workers also experienced significantly less trust in their Black supervisors than Blacks who reported to Blacks, the difference between White trust in Black supervisors and White trust in White supervisors was not significant. Thus, Whites did not distrust their Black supervisors more than they distrusted their White ones.

Perry and Mankin (2004) expanded the study of managerial trust to include Hispanics, 
Blacks and Whites. They focused on the extent to which trust in the CEO, trust in the organization, and levels of work satisfaction, including interrelationships of these variables, varied among different levels of management. After surveying firefighters and manufacturing employees, Perry and Mankin (2004) found significant differences based on race, namely that being a person of color was negatively related to trust in the supervisor. Specifically, they reported that employees of color place less trust in supervisors than do White employees. However, Perry and Mankin only focused on race of the subordinates - and did not consider the race of their supervisors.

Furthermore, conceptual literature written by Black psychologists and other diversity scholars who study how cultural factors shape human attitudes and behavior can help us understand the perceptions, beliefs, and behaviors of people of color in the American workplace. For example, scholars have often alluded to Blacks' distrust and suspicion of White-controlled medical research communities as a reason for their unwillingness to participate in medical research (Freimuth et al., 2001; Napoles-Springer et al., 2000).

Thus, it seems reasonable to suggest that people who are unwilling to trust Whitecontrolled medical research are unwilling to trust research conducted in other mostly White-controlled organizations. While much of the belief that there is a need to distrust Whites in authority may have been passed down from slavery and other significant historical events (e.g., Tuskegee syphilis studies in the 1930s), this perception may also be perpetuated through voluntary segregation of racioethnic communities and failure to form cross-racial friendships (Tatum, 1992). Thus, ethnics who choose to remain segregated and are unable or unwilling to form positive cross-racial relationships may bring their distrust and suspicions of Whites in authority into the workplace.

\section{Enhancing Trust in the Workplace}

Given the importance of trust in the organization and, in particular, the supervisorsubordinate relationship, we suggest that leaders in multicultural organizations pay closer attention to two environmental factors:

1. communication and demonstration of the organization's commitment to diversity, and 2. silence or acquiescent behavior among employees of color toward organizational leaders.

Greengard (1997) points out that "Unfortunately, there's often a disconnect between a company's objectives and what happens in the real world," (p. 46). A mere reference to valuing diversity in company policies is not enough. Moreover, such reference may set expectations that, if not met, could lead to a backlash in the organization. Organizational leaders who purport to value diversity should expect employees of color to evaluate their commitment to diversity, particularly in terms of access, treatment, and 
opportunities for people of color. While the organization may feel that its commitment to diversity is strong and obvious, people of color may perceive its commitment to be an attempt in window dressing (Brooks, 1999) and its diversity climate as less than hospitable (McKay et al., 2007).

Positive perceptions of an organization's diversity commitment could plausibly encourage less politically calculated behavior among employees of color. Black psychologists argue that people of color, particularly Black Americans, have developed coping and survival skills based on responding acquiescently to persons in authority irrespective of how they truly feel. Ames (as cited in Barnes, 1991) points out, "The ability to distinguish between oneself and the role one plays may be a critical operation for blacks. Consider the lyrics that go with an old black folk song; "we got one mind for white folk to see, "nother for what I know is me" (Ames, 1950, p. 194).

Figure 1 provides a diagram to help understand sub-optimal responses by employees of color to organizational research efforts. An integral feature is the employee of color's assessment of and satisfaction with his/her 1) organization's commitment to diversity coupled with his/her 2) personal commitment to the organization which affects a willingness to participate in organizational research efforts in multicultural organizations. This willingness is based upon trust in the organization and its management, especially immediate supervisors. The two environmental factors cited above - communication and demonstration of organizational commitment to diversity and acquiescent/silent behavior among employees of color - are key affective and behavioral markers that supervisors and organizational leaders should continuously scan for. Specifically, when employees of color perceive an organization's diversity commitment as lacking or when they acquiesce or are silent, they perceive participating in organizational research as fruitless and/or potentially unwise behavior.

While many potential mediators of trust exist, we highlight six that are most salient to our discussion of racioethnic challenges in organizational research: 1) cynicism toward diversity initiatives/programs, 2) quality of communications, 3) one's perceived acceptance by the organization, 4) organizational citizenship behavior, 5) fear of retaliation, and 6) racial/ethnic membership influence. As a result of a lack of managerial/organizational trust, employees of color choose acquiescent/compliant behavior (i.e., to respond but without full candor) or not respond at all when asked to participate in organizational research. 


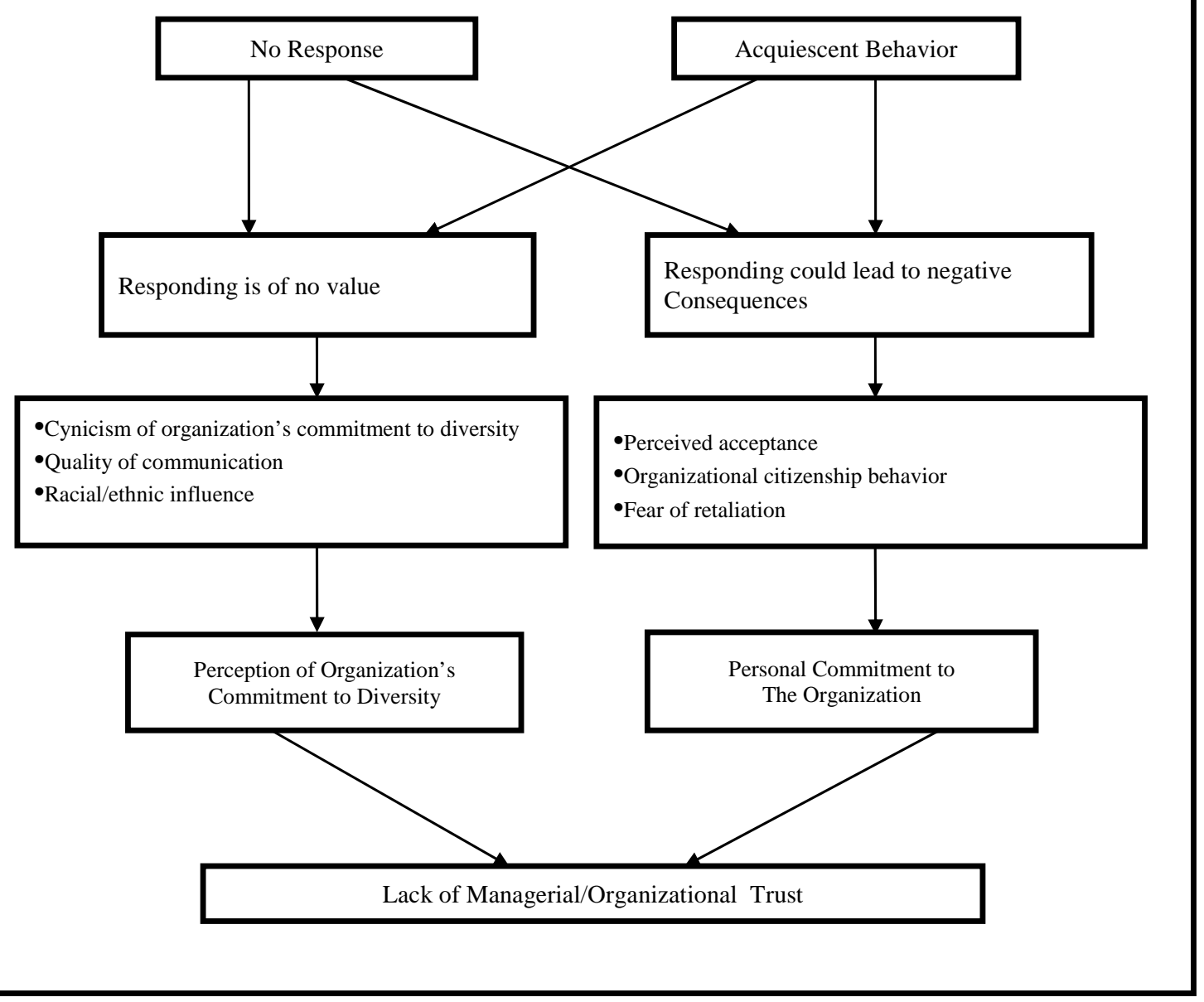

Figure 1: Employees of Color's Responses to Organizational Research Efforts

\section{Propositions}

Proposition 1: Responding openly is of little or no utility to employees of color, and thus responding is of no genuine value.

P1a: When employees of color perceive their organization's commitment to diversity as lacking or not credible, they are more likely not to respond or to respond acquiescently to organizational research efforts.

P1b: When employees of color perceive the numbers of racially or ethnically diverse employees as lacking in the organization, they are more likely not to respond or to respond acquiescently to organizational research efforts.

P1c: When employees of color are not fully engaged in the organization they are more likely not to respond or to respond acquiescently toward organizational research efforts. 


\section{Cynicism toward Diversity Initiatives/Programs}

Although many U.S. corporations have policies that emphasize their commitment to diversity, researchers have found that people of color are critical of pro-diversity efforts (Mor-Barak, Cherin, \& Berkam 1998; Minehan, 2002). Indicators of a strong, positive commitment to diversity include: a critical mass of diverse employees throughout the organization, inclusion of members of different racioethnic groups, recognition of withingroup differences, and constructive debates among diverse employees, including the discussions of sensitive issues such as injustice and workplace discrimination (Boykin, Franklin, \& Yates, 1979; Proudford \& Smith, 2003; Mehri, Giampetro-Meyer, \& Runnels, 2004). The perceived absence of one or all of these indicators could be a concern to employees of color - to the extent of non-response or acquiescent responses because they do not believe the organization is truly committed to diversity.

\section{Perceived Acceptance}

Employees of colors' perception of their acceptance by organizational members, and in particular, their inclusion into informal organizational relationships that can provide information, support, and social contacts (Igbaria and Wormley, 1992) may also influence how they respond to organizational research. Bowman (1991) suggests that due to intergroup inequalities such as the lack of people of color in most organizations' hierarchies and the difficulty of advancing within the organization, racioethnic group members often participate in organizational activities to promote both individual survival and collective social change. However, one of the most frequently reported problems that people of color face in an organization is limited access to, or exclusion from, informal interaction networks that allow for participation in these activities (Ibarra, 1993).

Thus, people of color who are not invited to join or participate in these informal networks may feel that they are not welcomed nor accepted by the organization. Additionally, inequities in pay, power/influence and the lack of cross-racial or ethnic relationships may also influence their decision to participate in organizational research efforts. Perceptions of being an outsider or the presence of discriminatory practices may lead some people of color to ask, "Why bother?" Moreover, some researchers have noted that people of color feel that educating white people is a burden (Bova, 2000; Combs, 2003) and that doing so would be of little-to-no value to them personally.

\section{Organizational Citizenship Behavior}

Organizational citizenship behavior or the willingness of employees to go beyond the 
minimum requirements of their job descriptions is vital to organizational effectiveness. Bowler (2006) states that organizational citizenship behavior consists of non-obligatory, informally influenced behaviors. He cites Podsakoff et al. (2000) who identify such informal influences as leader modeling, group cohesiveness, and leader member relations. Researchers have linked organizational citizenship behavior to trust in leadership and suggested that when a high level of trust exists in an organization, employees are less concerned with self-protection and are likely to exert extra effort (Podsakoff et al., 1990).

Donald (1960) asserts that a good indication of a person's willingness to respond to organizational surveys is their willingness to participate in organizational activities beyond the core requirements of their job. Signs that people of color may be reluctant to respond are: 1) an unwillingness to participate in constructive debates intended to enlighten others (Simons, Pelled, \& Smith, 1999), and 2) lack of participation in informal activities (e.g., attending organizational social functions, participating in athletic activities, going out for drinks after work with co-workers). Although organizational factors may exist which exclude people of color from participating in these activities, many simply choose not to participate (Ibarra, 1993). Two organizational factors that have been well documented in the literature are insider/outsider status (Igbaria \& Wormley, 1992; Proudford, \& Thomas, 1999) and discriminatory workplace practices (Cose, 1993; Grossman, 2000).

P1d: When an organization fails to communicate how its research will benefit employees of color (both for the individual and for their racioethnic group), employees of color are more likely not to respond or not to respond candidly to organizational research efforts.

P1e: When an organization fails to communicate study results or result-based outcomes in a timely manner, the more likely employees of color will not respond or not respond candidly to organizational research efforts.

\section{Communication Quality}

Quality of communication between management and employees can be one of the strongest influences of trust (Roberts \& O'Reilly, 1974). The higher the perceived degree of trust, the more likely one would observe disclosures of more truthful, relevant, and complete data about problems (Wrightsman, 1974; Zand, 1971). Respondents in the Perry and Mankin (2004) study stated that communication was a key factor in their ability to trust their leaders, specifically citing: "must be truthful," "honest," "share the real information," and "tell things straight" in their feedback. Moreover, Sias (2005) argues that managers should be encouraged to share high quality information with all employees, not just a chosen few. 
Although diversity experts and researchers have sought to outline the benefits of an organization's ability to gain insights about their customers through their employees (McCuiston, Wooldridge, \& Pierce, 2004), rarely have benefits to individual employees been identified. Akbar (1991) calls for research that results in programs that have immediate relevance in correcting the respondents' perceived less-than-optimal condition. He maintains, "... research must affirm benefit and not function as research for research's sake as is the case for some traditional research. The objective should be to apply directly research findings to some problem or goal which would enhance the development of our communities" (Akbar, 1991; p.721). Although Akbar focuses on field research in the Black community, we believe his concerns may be extrapolated to how people of color may perceive organizational research and that the community of concern is any racioethnic group to which the respondent belongs within the organization.

To generate initial interest and motivation, virtually all organizational surveys include an introductory cover letter from the CEO, president, functional manager, or human resource manager that informs prospective respondents about the benefits of responding to the survey. However, perhaps in their quest for brevity, organizational leaders may fail to include convincing information to motivate participation - including genuine efforts to enhance diversity commitment. Bowman (1991) argued that people of color may be interested in a survey's content, but do not sense that responding to the survey will address their concerns. People of color may understand that their assessment of the organization's competitive and functional strategies is beneficial to the organization, but not to them personally or as a collective group within that organization. While satisfaction surveys can enhance the diversity climate and increase employment and advancement opportunities for people of color, employees also need evidence that their concerns, expressed through previous feedback systems were taken seriously.

P2: Candid responses by employees of color can lead to perceived adverse consequences.

While non-response to surveys by people of color may be linked to being identified via racial or ethnic data, non-response may further be exacerbated by the fear that they could face retaliation-even if the organization promises not to retaliate-should their identity be revealed.

P2a: When employees of color believe that they can be identified, they are more likely not to respond or to respond acquiescently to organizational research efforts.

P2b: When employees of color fear retaliation by organizational leaders, they are more likely not to respond or to respond acquiescently to organizational research efforts.

Fear of Identification and Retaliation 
Although it has been well documented in the literature that fear of retaliation is an important determinant of employees' willingness to voice dissent, fear of retaliation has not been empirically linked to non-response to organizational surveys. While one could argue that fear of identification is synonymous to fear of retaliation, they have different conceptual meanings and operational definitions. While both are potentially detrimental, identification (the ability to trace a response back to an individual employee, c.f., Berdie, Anderson, Niebuhr, 1986) does not ensure action will be taken. Thus, there may be no consequences to the respondent. On the other hand, retaliation explicitly denotes negative consequences (e.g., harassment, labeling as a troublemaker; Brooks, 1999), lower performance ratings and promotion opportunities (Feuille \& Delaney, 1993), and termination. We point out that fear of identification is an antecedent to the fear of retaliation; thus, fear of retaliation is a probable concern to people of color.

Researchers and organizations primarily focus on employee's fear of identification, using at times intense measures to ensure confidentiality and anonymity during the research process. To protect the employees' anonymity and encourage people to participate and/or provide accurate responses, names of respondents are usually not required. However, codes can be used to link respondents to demographics (gender, race, ethnicity), and operations (function, location, plant department). For employees of color, survey participation is confounded further by a lack of a critical mass of diverse employees in most organizations. Lack of diversity in the workforce increases risk of identification and perhaps retaliation. Some respondents logically fear that when a relatively small number of employees within their racioethnic group exist, they can be identified by the matching of surface level racioethnic data with other data provided by the respondent.

While distrust of the research process (Singer, Mathiowetz, \& Couper, 1993) is of major concern, not knowing how managers will or will not use the data obtained may be more important to people of color. Two specific concerns are: 1) some organizations feed survey results into performance management decisions and 2) survey results could be used to control subordinates. While the practice of feeding survey results into performance management decisions speaks to a lack of integrity of the human resource function, it effectively dissuades employees from responding, especially if they perceive doing so could potentially harm them. Given that evaluation and control are within the purview of management, a conflict exists when employees expect fairness and autonomy, yet believe research may be used to micro-manage less-talented employees. As an exacerbating factor, employees of color are often seen as affirmative action hires (Key \& Cox Edmondson, 1999) and may be viewed as less talented than Whites.

Gant et al. (1993) found that Blacks report being undermined by their supervisor and coworkers significantly more often than other employees. As a result, Blacks had a 
higher incidence of irritability, depression, anxiety, and depersonalization. Schweitzer, Hershey and Bradlow (2006) argue that even when management promises that it will stop behaving untrustworthily, people never fully recover when the same untrustworthy actions and deceptions are continued.

Brickson (2000) argues that people of color who have less power than others in the organization may fear that their position is more precarious than that of majority group members. However, Kassing (1998) argues that due to their protective class status under Title VII, employees of color may be willing to express their concerns because they possess organizational leverage that provides them with a sense of immunity against retaliation. We argue that although they have protective status, some employees of color sense that proving discrimination is not worth the risk. Unlike whistle-blower legislation, which seeks to protect employees who voice dissent about illegal and ethical violations, employees who openly voice dissent about bad management practices have no legal recourse unless they can prove the retaliation can be tied to their race or another protective status. Moreover, legal cases often take time to resolve and retaliation may continue as the case lags on.

P2c: When employees of color perceive that they do not share positive organizational perceptions with others within their racioethnic group, they are more likely not to respond for fear of being identified by management.

P2d: When employees of color perceive that they do not share negative organizational perceptions with others within their racioethnic group, they are more likely not to respond or to respond acquiescently to organizational research efforts, based on their fear of being ostracized by racioethnic group members.

\section{$\underline{\text { Racial/Ethnic Identity Influence }}$}

People who share a common racial heritage often perceive that they also have shared experiences with others in their racial group (Helms, 1990) which can result in a collective racial identity within organizations. Racial identity is based on the extent that an individual's self-concept is defined by membership in a particular racial/ethnic group, the level of attachment felt toward the group, and the extent of participation in cultural activities associated with group membership (Phinney, 1992). When racial identity is high among a particular racioethnic group in an organization, for example, it is likely that perceptions of fairness, justice, equity and progress toward diversity goals will be highly shared among the members of that group. Depending upon the organization's commitment to diversity, especially as perceived by people of color, race/ethnic identity may have an integral role in explaining the presence and the degree of non-response and candor.

White (1991) argues that Blacks have a healthy sense of suspiciousness which has 
caused them to develop as youngsters a mental toughness and survival skills (in terms of coping with life) that allows them to "jive" authority figures (p. 12). It is reasonable to believe that Blacks may continue to deceive or be less candid with authority figures when they become adults as they deem necessary. According to Cox Edmondson and Munchus (2007), to avoid division, employees (of all races) may choose to remain silent when trust is low, and when they feel no sense of urgency to voice dissent. Although some will discuss their concerns with managers, there is often a discrepancy between their expressed attitudes and their beliefs and actions (Quinn, 1997; Morrison \& Millikin, 2000). Quinn (1997) suggests that people tell others what they think they want to hear.

Furthermore, Kelman (1958) argues that people cooperate in order to achieve a favorable reaction from another person or group. "He/she adopts the induced behavior not because he/she believes its content - but because he expects to gain specific rewards or approval and avoid specific punishment or disapproval by conforming (p.53). Hayes (1991) argues that Blacks have developed role-taking (Turner, 1956) and roleplaying skills that allow them to survive, fit in, and advance within the organization. Thus, even if they complete an organizational survey, they may respond by telling organizational leaders what they think they want to hear or not respond at all.

\section{Discussion}

Throughout this paper, lack of managerial/organizational trust has been cited as a basis for understanding the perceptions, beliefs, and behaviors commonly held by employees of color toward organizational research. Managerial/organizational trust appears to be both a requirement for and an outcome of the research process. The importance of an employee's trust in an organization, or more precisely, trust in the power structure responsible for running the organization, cannot be underestimated as a potential explanation for the less than desired participation level among employees of color in organizational research.

Lack of trust does not necessarily derive from personal, face-to-face work situations gone sour. Workers may perceive that low trust is in their best interest because they have had no evidence that a higher trust level is in their better interest. If we consider this low trust threshold among people of color a cogent explanation for survey nonresponse, their behavior could be equally explained as a cost-benefit ratio based decision-making process, or as a personalized risk management strategy.

When employees of color resort to acquiescent behaviors toward management they may achieve short-term gains but in the end, they fail to adequately effect the change that is necessary to redirect their supervisors and, ultimately, the organization as a whole. If supervisors receive cues from their subordinates and co-workers that signal "all is well" then the likelihood of their present behaviors continuing is increased. Top management must pay closer attention to the relationships between lower level management/supervisors and their subordinates of color. Supervisors who are found to 
have behaved unjustly toward their subordinates (of any racioethnicity) should face disciplinary consequences, for example.

The easiest way to proactively address deficiencies of participation in organizational research among any racioethnic group is also the most time-intensive: the development of a diverse organizational workforce and culture that is supportive of differences in the workplace. However, this process cannot be accomplished within the space of monthly, quarterly or annual earnings reports-not atypical of the time needed to do survey research. As mentioned earlier, a critical mass of diverse employees throughout the organization, inclusion of members of different racioethnic groups, recognition of withingroups differences, and constructive debates between diverse employees (including the discussions of sensitive issues such as injustice and workplace discrimination; Boykin et al.,1979; Proudford \& Smith, 2003; Mehri, Giampetro-Meyer, \& Runnels 2004) are necessary. These criteria may not be the panacea to ensure that people of color are willing to fully engage in the research process, but we assert that the presence of these criteria offer a greater likelihood that more people of color will be willing to participate and with increased candor.

The literature inferentially recommends the need for management and staff to be involved from the beginning of a decision-making process. By developing a better understanding of the types and scale of problems faced by their employees of color, management would be able to identify, develop, and use decision-making theories and strategies that involve them - not only in organizational research - but in other opportunities where employees of color's full participation is vital to the organization's success.

\section{New Directions for Research}

The purpose of this paper has been to stimulate thinking and offer insights to those who plan and conduct organizational research, particularly organizational satisfaction surveys and surveys to access the opinions of employees regarding organizational phenomena. Although we have focused on employees of color in our discussion, many concerns raised about this group may apply to other strata as well (e.g., gender, sexual orientation). Our observations and recommendations are by no means intended to be an end point, but rather a starting place.

Although the propositions presented in this paper have been theorized and are consistent with the literature and its inferences, there is little direct empirical support for them. Thus, we see value in testing them. Earlier in this paper, we acknowledged problems within the extant literature on managerial trust; primarily, there is a lack of concern for race - even when race is measured or considered.

Further, management researchers in the U.S. have focused much of their attention on the differences between Black and White employees. Given the great influx of Hispanics and Asians into the American workforce, researchers should be increasingly able to 
provide insights into how these groups are impacting the workplace. We encourage studies among and between all racioethnic groups to more adequately ascertain the importance of trust and how it affects employee organizational citizenship behavior, as well as how employees value diversity climates within majority and multicultural organizations.

To broaden the potential utility of these propositions, we recommend a literature examination of other diversity categories. Specifically, might the approaches and propositions advocated here have similar relevance and help raise participation rates and candor among other diverse groups, such as women within male-dominated fields? Additionally, while studies of managerial trust have focused on the supervisorsubordinate relationship, more studies should be conducted to provide insights on peer relationships. How much do managers of color trust their peers? How is that trust or distrust manifested (e.g., How has managerial trust affected their careers; how has it influenced their organization's effectiveness)? How have managers of color addressed their own beliefs and perceptions regarding race-related issues in the workplace?

Finally, additional studies on the supervisor-subordinate relationship are needed. How do managers of color influence their employees of color's perceptions? How have these managers addressed their subordinates' perceptions, beliefs and behaviors? How have their subordinates responded - both White and non-White?

Organizations must make good on their commitment to diversity. What we have provided are beginning steps so that researchers can garner empirical strength to assess an organization's progress with regard to diversity participation and candor. We strongly encourage organizational leaders to promote discussing difficult diversity issues in the workplace, particularly within organizations that purport to value diversity. Genuine, respectful and challenging conversations about race and ethnicity will ultimately become commonplace and acceptable. Employees of color should be encouraged to fully engage in, and not merely respond to a range of organization research efforts, not just surveys. Regardless of the research method, research design, or their general attitudes toward participating in organizational surveys, employees of color will continue to be non-responsive or less responsive to research efforts if they perceive that their concerns are neither valued nor adequately addressed.

\section{References}

Akbar, N. (1991). Paradigm of African America research. In Reginald L. Jones, (Ed.), Black psychology (pp. 709-725). Berkeley, CA: Cobb and Henry.

Ames R. (1950). Protest and irony in Negro folkson, Reprint from Science and Society, v. 14, summer, 1950 and v. 15, spring, 1951. Bobbs-Merrill, Indiana.

Aranda, E.M., \& Rebollo-Gil, G. (2004). Ethnoracism and the "sandwiched" minorities. The American Behavioral Scientist, 47, 910-927. 
Atkinson, S. (2004). Senior management relationships and trust: An exploratory study. Journal of Managerial Psychology, 19, 571-587.

Atwater, I., (1988). The relative importance of situational and individual variables in predicting leader behavior. Group and Organization Studies, 13, 290-310.

Barnes, E.J. (1991). The Black community as a source of positive self-concept for Black children: A theoretical perspective. In R. L. Jones, (Ed.), Black Psychology (pp. 667692). Berkeley, CA: Cobb and Henry.

Berdie, D. R., Anderson J. F., \& Niebuhr, M. A. (1986). Questionnaire design and use. Metuchen, NJ: The Scarecrow Press, Inc.

Birnbaum, H. \& Weston, R. (1974). Home ownership and the wealth position of black and white Americans. Revenue Income Wealth, 21,103-118.

Bova, B. (2000). Mentoring revisited: The Black woman's experience. Mentoring \& Tutoring, 8 (1), 5-16.

Bowler, W.M. (2006). Organizational goals versus the dominant coalition: A critical view of the value of organizational citizenship behavior. Journal of Behavioral and Applied Management, 7, 258-273.

Bowman, P. J. (1991). Race, class and ethics in research: Belmont principles to functional relevance. In R. L. Jones, (Ed.), Black Psychology (pp. 747-766). Berkeley, CA: Cobb and Henry.

Boykin, A. W., Franklin, A. \& Yates, J. F. (1979). Research directions of Black psychologists. New York: Russell Sage.

Brickson, S. (2000). The impact of identity orientation individual and organizational outcomes in demographically diverse settings. Academy of Management Review, $25,82-101$.

Brooks, A. K. (1999). Critical reflection as a response to organizational disruption. Advances in Developing Human Resources, 3, 67-97

Church, A. H. (2001). Is there a method to our madness? The impact of data collection methodology on organizational survey results. Personnel Psychology, 54, 937-970.

Combs, G. M. (2003). The duality of race and gender for managerial African American women: Implications of informal social networks on career advancement. Human Resource Development Review, 2, 385-406.

Cose, E. (1993). The rage of a privileged class. New York: HarperCollins. 
Cox Edmondson, V. (2006). Organizational surveys: A system of employee voice. Journal of Applied Communication Research. 34, 307-310.

Cox Edmondson, V., \& Munchus, G. (2007). Managing the unwanted truth: A framework for dissent strategy. Journal of Organizational Change Management, 20,747-760.

Cox, T. (2004). Problems with research by organizational researchers on issues of race and ethnicity. The Journal of Applied Behavioral Science, 40, 124-145.

Dirks, K. T., \& Ferrin, D. L. (2001). The role of trust in organizational settings. Organizational Science,12, 450.

Donald, M. (1960). Implications of nonresponse for the interpretation of mail questionnaire data. Public Opinion Quarterly, 24, 99-114.

Etzioni, A. (1995). The spirit of community: Rights, responsibilities and the communitarian agenda. London: Fontana.

Feagin, J. (2000). Racist America: Roots, current realities and future reparations. New York, NY: Routledge.

Feuille, P. \& Delaney, J. T. (1993). The individual pursuit of organizational justice: Grievance procedures in nonunion workplaces. In G. R. Ferris \& K. M. Rowland, (Eds.) Research in Personnel and Human Resource Management, (pp.187-232). Greenwich, CT: JAI Press.

Fukuyama, F. (1995). Trust: The social virtues and the creation of prosperity. Free Press, New York.

Fowler, F. J. Jr. (1984). Survey research methods. Thousand Oaks, CA: Sage.

Freimuth, V. S., Quinn, S. C., Thomas, S. B., Cole, G., Zook, E., \& Duncan, T. (2001). African Americans' views on research and the Tuskegee syphilis study. Social Science \& Medicine, 52, 797-808.

Gant, L. M., Nagda, B. A., Brabson, H. V., Jayaratne, S., Chess, W. A., \& Singh, A. (1993). Effects of social support and undermining on African American workers' perceptions of coworker and supervisor relationships and psychological well-being. Social Work, 38, 158-164.

Glaeser, E. L., Laibson, D., Scheinkman, J. A., \& Soutter, C. L. (1999). What is Social Capital? The determinants of trust and trustworthiness. National bureau of economic research, Working Paper.

Gomez, C. \& Rosen, B. (2001). The leader-member exchange as a link between 
managerial trust and employee empowerment. Group \& Organization Management, 26, 53-69.

Greengard, S. (1997). 50\% of your employees are lying, cheating \& stealing. Workforce, 76 (10), 44-53.

Grossman, R. J. (2000). Race in the workplace. HR Magazine, 41-45.

Groves, R. M., Cialdini, R. B., \& Couper, M. P. (1992). Understanding the Decision to participate in a survey. The Public Opinion Quarterly, 56, 475-495.

Hacker, A. (1995). Two nations: Black and White, separate, hostile, unequal. New York: Ballantine.

Hayes, R.V. 1991. African American strengths: A survey of empirical findings. In R. L. Jones, (Ed.), Black Psychology, (pp. 379-400.) Berkeley, CA:Cobb \& Henry.

Helms, J. (1990). Black and White racial Identity: Theory, research, and practice. London, Praeger Publishers.

Ibarra, H. (1993). Personal networks of women and people of color in management: A conceptual framework. Academy of Management Review, 18, 56-87.

Igbaria, M., \& Wormley, W.M. (1992). Organizational experience and career success of MIS professionals and managers: An examination of race differences. MIS Quarterly, 16, 507-529.

Ilgen, D.R. and Youtz, M.A. (1986). Factors affecting the evaluation and development of minorities in organizations. In K. Rowland and G. Ferris (Eds.) Research in Personnel and Human Resource Management (pp. 307-337). Greenwich, CT: JAI Press.

Jackson, S., May, K. E., \& Whitney, K. (1995). Understanding the dynamics of diversity in decision making teams. In R. A. Guzzo \& E. Salas (Eds.), Team effectiveness and decision making in organizations (pp. 204-261). San Francisco: Jossey-Bass.

Jeanquart-Barone, S. (1993). Trust differences between supervisors and subordinates: Examining the role of race and gender. Sex Roles, 29 (1/2), 1-11.

Kassing, J. W. (1998). Development and validation of the organizational dissent scale. Management Communication Quarterly, 12, 183-229.

Kelman H. C. (1958). Compliance, identification, and internalization: Three processes of attitude change. Journal of Conflict Resolution, 2, 51-60.

Key, S. \& Cox Edmondson, V. (1999). Does social cognitive theory elucidate Black 
executives' orientation to corporate social responsibility? Business \& Professional Ethics Journal, 18 (2), 35-56.

Mayer, R. C., Davis, J. H., \& Schoorman, F. D. (1995). An integration model of organizational trust. Academy of Management Review, 20, 709-734.

McCuiston, V. E., Wooldridge B. R., \& Pierce C. K. (2004). Leading the diverse workforce: Profit, prospects and progress. Leadership \& Organizational Development Journal, 25 (1/2), 73-92.

McKay, P. F., Avery, D. R., Tonidandel, S., Morris, M. A., Hernandez, M., \& Hebl, M. R. (2007). Racial difference in employee retention: Are diversity climate perceptions the key? Personnel Psychology, 60, 35-62.

Mehri, C., Giampetro-Meyer, A., \& Runnels, M.B. (2004). One nation, indivisible: The use of diversity report cards to promote transparency accountability and workplace fairness. Journal of Corporate \& Financial Law, 9, 395- 448.

Minehan, M. (2002). What's new in corporate diversity? Retrieved October 3, 2005, from Employment Trend Website: www.workplacediversity.com/about/press-7-1502.asp.

Mor-Barak, M.E., Cherin, D. A., \& Berkman, S. (1998). Organizational and personal dimensions in diversity climate: Ethnic and gender differences in employee perceptions. The Journal of Applied Behavioral Science, 34, 82-104.

Morrison, E. W., \& Milliken, F. J. (2000). Organizational silence: A barrier to change and development in a pluralistic world. Academy of Management Review, 25, 706-725.

Napoles-Springer, A. M., Grumbach, K., Alexander, M., Moreno-John, G., Forte, D., Rangel-Lugo, M. (2000). Clinical research with older African Americans and Latinos: Perspectives from the community. Research on Aging, 22, 668-691.

Nkomo, S. M. (1992). The emperor has no clothes: Rewriting "race in organizations". Academy of Management Review, 17, 487-513.

Perrone, V., Zaheer, A., McEvily, B. (2003). Free to be trusted? Organizational constraints on trust in boundary spanners. Organization Science, 14, 422-439.

Perry, R.W., Mankin, L.D. (2004). Understanding employee trust in management: Conceptual clarification and correlates. Public Personnel Management. 33, 277-290.

Phinney, J.S. (1992). The Multigroup ethnic identity measure: A new scale for use with diverse groups. Journal of Adolescent Research, 7, 156-176.

Podsakoff, P.M., MacKenzie, S.B., Moorman, R.H. \& Fetter, R. (1990). Transformational 
leader behaviors and their effect on followers trust in leader, satisfaction, and organizational citizenship behaviors. Leadership Quarterly, 1, 107-42.

Podsakoff, P. M., Mackenzie, S. B., Paine, J. B., Bacharach, D. G. (2000). Organizational citizenship behaviors: A critical review of the theoretical and empirical literature and suggestions for future research. Journal of Management, 26, 513-563.

Proudford, K. L., \& Smith, K. K. (2003). Group membership salience and the movement of conflict: Reconceptualizing the interaction among race, gender, and hierarchy. Group \& Organizational Management, 28, 18-45.

Proudford, K. L., \& Thomas, K. M. (1999). Black women as outsiders within: A new set of challenges. The Diversity Factor, 7 (3), 22-27.

Quinn, J. J. (1997). Personal ethics and business ethics: The ethical attitudes of owner/managers of small business. Journal of Business Ethics, 16, 119-127.

Ritter B.A., Fischbein R.L., \& Lord R.G. (2005). Implicit and explicit expectations of justice as a function of manager and subordinate race. Human Relations, 8 , 15011521.

Riordan, C.M., Gatewood, R. D., Barnes Bill, J. (1997). Corporate image: Employee reactions and implications for managing corporate social performance. Journal of Business Ethics, 16, 401-412.

Roberts, K.H. \& O'Reilly. (1974). Failure in upward communications in organizations: three possible culprits. Academy of Management, 17, 205-15.

Robinson, S. L. (1996). Trust and breach of the psychological contract. Administrative Science Quarterly, 41, 574-599.

Rogelberg, S.C. Spitzmüeller, C., Little, I., Reeve, C.L. (2006) Understanding response behavior to an online special topics organizational satisfaction survey. Personnel Psychology, 59, 903-922.

Rousseau D. M., Sitkin, S. B., Burt, R. S. \& Camerer, C. (1998). Not so different after all: A cross-discipline view of trust. Academy of Management Review, 23, 393404.

Schweitzer, M. E., Hershey, J. C., \& Bradlow, E.T. (2006). Promises and lies: Restoring violated trust. Organizational Behavior and Human Decision Processes, 101,1.

Sias, P.M. (2005). Workplace relationship quality and employee information experiences. Communication Studies, 56, 375-395.

Sims, R. L. (2000). The relationship between employee attitudes and conflicting 
expectations for lying behavior. The Journal of Psychology, 134, 619-633.

Simons, T., Pelled, L. H., \& Smith, K. A. (1999). Making use of difference: Diversity, debate, and decision comprehensiveness in top management teams. Academy of Management Journal,42, 662-673.

Simsek, Z., \& Veiga, J. F. (2001). A primer on Internet organizational surveys. Organizational Research Methods, 4, 218-235.

Singer, E., Mathiowetz, N. A., \& Couper, M. P. (1993). The impact of privacy and confidentiality concerns on survey participation: The case of the 1990 U.S. census. Public Opinion Quarterly, 57, 465-482.

Sutton, R. J., \& Schurman, S. J. (1988). On studying emotionally hot topics: Lessons from an investigation of organizational death. In D. N. Berg \& K. K. Smith (Eds.), The self in social inquiry researching methods (pp. 333-349). Thousand Oaks, CA: Sage.

Tatum, B.D. (1992). Talking about race, learning about racism: the application of racial identity development theory in the classroom. Harvard Educational Review, 62, 1-24.

Turner, R.H. (1956). Role-taking: Process versus conformity. In A.M. Rose (Ed.), Human behavior and social process: An interaction approach (pp. 316-328). Boston, MA: Houghton Miller.

Watson, W. E., Kumar, K., \& Michaelsen, L. K. (1993). Cultural diversity's impact on interaction process and performance: Comparing homogeneous and diverse task groups. Academy of Management Journal, 36.

Werhane, P.H (1999). Justice and trust. Journal of Business Ethics, 21 (2/3), 237-249.

White J. \& Parham T. (1990). The Psychology of Blacks: An African-American Perspective. Englewood Cliffs, NJ, Prentice-Hall Inc.

Wrightsman, L. S. (1974). Assumptions about human nature: A social psychological approach. Monterrey, CA, Brooks Cole.

Zand, D.E. (1971). Trust and managerial problem solving. Administrative Science Quarterly, 17, 229-39.

Zucker, L.G. (1986). The production of trust: Institutional sources of economic structure. In Staw, B.M., \& Cummings, L.L. (Eds.), Research in organizational behavior (pp. 53-111), Greenwich, CT, JAI Press. 